\title{
Fermentation characteristics and nutritional value of elephant grass ensiled with old man saltbush ${ }^{1}$
}

\section{Otanael Oliveira dos Santos ${ }^{2}$, Gherman Garcia Leal de Araújo ${ }^{3}$, Claudio Mistura ${ }^{4}$, Luiz Gustavo Ribeiro Pereira ${ }^{5}$, Tadeu Vinhas Voltolini ${ }^{3}$, Mércia Virginia Ferreira dos Santos ${ }^{6}$, Josivânia Rodrigues de Araújo²}

\author{
${ }^{1}$ Research financed by BNDES. \\ 2 Universidade Federal do Vale do São Francisco (UNIVASF), Petrolina, PE, 56300-000, Brasil \\ ${ }^{3}$ Embrapa Semiárido, Petrolina, PE, Brasil. CNPq fellow. \\ ${ }^{4}$ Universidade do Estado da Bahia (UNEB), Campus III, DTCS, Juazeiro, BA, Brasil. \\ ${ }^{5}$ Embrapa Gado de Leite (CNPGL), Juiz de Fora, MG, Brasil. \\ ${ }^{6}$ Universidade Federal Rural de Pernambuco (UFRPE), Departamento de Zootecnia, Recife, PE, Brasil. CNPq fellow.
}

ABSTRACT - The effects of the addition of saltbush on the fermentation characteristics and nutritional value of silages of elephant grass (Pennistum purpureum Schum.) were studied through a completely randomized design with six old man saltbush (Atriplex nummularia Lind) levels (0, 20, 40, 60, 80 and $100 \%$ ) in substitution of the grass natural matter, with six replicates. Elephant grass presented $18.9 \%$ dry matter (DM) and silages were produced in experimental PVC silos, which were open at 70 days after ensilage. The increasing old man saltbush levels had increasing linear effect on the DM content of silages. There was quadratic effect for the contents of lactic and acetic acids and in vitro DM digestibility. Contents of butyric acid were negligible. Values $\mathrm{pH}$ of and $\mathrm{N}-\mathrm{NH}_{3}$ contents had increasing linear effect. Linear effect of the increasing levels of old man saltbush was verified on the CP contents. Neutral detergent fiber, total carbohydrates and ether extract were not affected, whilst acid detergent fiber content showed decreasing linear effect. The addition of old man saltbush in the ensilage of elephant grass favored the fermentation process, promoting good lactic acid contents and reducing acetic acid, $\mathrm{pH}$, dry matter loss and ammoniacal nitrogen, in addition to improving the nutritional quality of the elephant grass silages.

Key Words: acid detergent fiber, ammonia nitrogen, crude protein, neutral detergent fiber, $\mathrm{pH}$

\section{Introduction}

The difficulty to produce good-quality feed in certain locations and times of the year is the main reason that drives producers in general to produce silage. In the northeast of Brazil, the irregularity of rainfall distribution affects the productivity of herds, for significantly reducing the offer of quality roughage to animals in the critical period of the year.

Among the forages utilized for this purpose, the elephant grass (Pennisetum purpureum Schum.) stands out in several research studies conducted in the Country (Bernardino et al., 2005; Carvalho et al., 2007), especially for presenting elevated dry matter production (Santos et al., 2010).

In spite of this potential for silage production, the low soluble carbohydrate content of this forage is a limiting factor, and thus, it confronts the parameters recommended for production of good-quality silage. The ensilage of grasses with low content of these carbohydrates promotes losses during the ensilage process (Bernardino et al., 2005) and, in coalition with the high content of humidity of the forage, may promote the development of bacteria of the Clostridium genus. The development of these bacteria generates secondary unwanted fermentations and the formation of butyric acid, which characterizes silages of low quality (McDonald, 1981).

In light of this, several authors have sought for alternatives to increase the soluble carbohydrate content in the ensiled mass of elephant grass and improve its nutritional value, such as the technique of grass withering (Carvalho et al., 2007) and the use of additives aiming to promote improvement in the fermentation conditions of the silage, especially by the increase in the dry matter (DM) content.

Old man saltbush (Atriplex nummularia Lind) has potential to be utilized in the feeding of ruminants of the northeast region, especially in the semi-arid region, due to its high resistance to salinity and drought, in addition to presenting high content of crude protein and high capacity of phytomass production. Reports in the literature indicate the feasibility of utilizing this forage plant in the feeding of cattle, sheep and goats in the form of hay. However, results from research studies evaluating the utilization of this forage as silage are still incipient.

The objective of this study was to evaluate the fermentation characteristics and the nutritional value of 
elephant grass silages ensiled with increasing levels of old man saltbush.

\section{Material and Methods}

The forages utilized for ensilage in this experiment were elephant grass (Pennisetum purpureum Schum) and old man saltbush (Atriplex nummularia Lind), which were grown in the Agrarian Sciences campus of Universidade Federal do Vale São Francisco and at Embrapa Semiárido, respectively, in Petrolina, Pernambuco, Brazil (Table 1).

The experimental design was completely randomized, with six treatments and six replicates. Elephant grass was gradually replaced at $0,20,40,60$ and $100 \%$ by old man saltbush, on a natural matter basis. The elephant grass (80 days of growth) was harvested with forage shredder coupled to the tractor; the cut was done manually, at $10 \mathrm{~cm}$ from the soil and after, chopped in $2 \mathrm{~cm}$ fragments through stationery shredder. The old man saltbush was harvested at 12 months of age.

Thirty-six PVC experimental silos with $50 \mathrm{~cm}$ height by $10 \mathrm{~cm}$ diameter were utilized. Immediately after opening of silos, with the aid of a manual pressing machine, the silage juice was obtained, for determination of $\mathrm{pH}$ with the aid of a hydrogen potentiometer according to Silva \& Queiroz (2002). The ammoniacal nitrogen content, in relation to the total nitrogen ( $\left.\mathrm{N}-\mathrm{NH}_{3} / \mathrm{NT}\right)$, was dosed after distillation with magnesium oxide and calcium chloride (AOAC, 1980). One of the decisive factors of the efficiency of the forage conservation is the loss of nutrients that happens from the harvesting to the ingestion by the animal. There are three main types of losses: mechanical, biochemical and by effluents. At the determination of the dry matter losses of the ensiled material, the silos were weighed before and after forage deposition. The weight of the silos was also utilized for the determination of the DM losses of the ensiled material during the fermentation process, by the difference between the weights of the masses of the silos obtained at

Table 1 - Chemical composition of elephant grass and old man saltbush before ensilage (\%DM)

\begin{tabular}{lcc}
\hline Item & $\begin{array}{c}\text { Elephant } \\
\text { grass }\end{array}$ & $\begin{array}{c}\text { Old man } \\
\text { saltbush }\end{array}$ \\
\hline Dry matter (DM) & 18.96 & 34.96 \\
Mineral matter & 13.19 & 16.54 \\
Organic matter & 86.81 & 83.46 \\
Crude protein & 5.85 & 9.01 \\
Total carbohydrates & 79.50 & 72.80 \\
Ether extract & 1.50 & 1.65 \\
Neutral detergent fiber & 78.05 & 68.19 \\
Acid detergent fiber & 43.83 & 39.07 \\
In vitro dry matter digestibility & 56.43 & 49.11 \\
\hline
\end{tabular}

their filling and opening, multiplied by the respective DM contents.

For analysis of organic acids, $10 \mathrm{ml}$ of the juice were diluted in water, acidified with $50 \%(\mathrm{v} / \mathrm{v})$ sulfuric acid and filtered through Whatman filter paper (Kung Jr. \& Ranjit, 2001). In $2 \mathrm{~mL}$ of the filtered solution, $1 \mathrm{~mL}$ of $20 \%$ (v/v) metaphosphoric acid was added; this sample was centrifuged. The contents of lactic, acetic and butyric acids were measured by high-resolution liquid chromatography (HRLC). Also, the material taken was homogenized and samples from it were collected and dried in forced air circulation oven at $55^{\circ} \mathrm{C}$, for 72 hours. Next, samples were ground in Willey mill with 1-mm sieve and analyzed for: dry matter (DM), organic matter (OM), ether extract (EE), crude protein (CP), neutral detergent fiber (NDF), acid detergent fiber (ADF), according to recommendations by Silva \& Queiroz (2002), and in vitro dry matter digestibility was according to the two-step methodology of Tilley \& Terry (1963), described by Silva \& Queiroz (2002). For determination of total soluble carbohydrates $(\mathrm{TCH})$ and non-fibrous carbohydrates (NFC), the following equations were utilized, according to Sniffen et al. (1992): $\mathrm{TCH}=100$ $-(\mathrm{CP} \%+\mathrm{EE} \%+\mathrm{MM} \%)$ and $\mathrm{NFC}=100-(\mathrm{CP} \%+\mathrm{EE} \%+$ $\mathrm{MM} \%+\mathrm{NDF} \%)$.

The results were submitted to variance analysis, considering as sources of variation the addition of old man saltbush in the ensilage of elephant grass, and, when significant, the polynomial analysis regression for the adjustment of the best equation was carried out, through its significance, the $\mathrm{R}^{2}$ value and the behavior of the biological response, utilizing the software WinStat (Machado \& Conceição, 2002).

\section{Results and Discussion}

Decrease in the dry matter loss (Figure 1) by the increment of old man salt bus in the silage was observed, demonstrating that the $75.28 \%: 24.72 \%$ old man salt bush:elephant grass ratio promoted smallest loss, with $0.985 \%$, and highest in $0 \%: 100 \%$, with $2.57 \%$. This can be understood by the lower dry matter contents of the elephant grass $(18.86 \%)$, in comparison with the old man saltbush (31.28\%) in the original material. The lower dry matter loss values are possible related to the low proteolysis of the material ensiled during the fermentation by the inclusion of old man saltbush.

The ammoniacal $\mathrm{N}$ content in the silages was affected $(\mathrm{P}<0.05)$ by the old man saltbush levels and presented variation of $4.11 \%$ and $1.34 \%$ in the 0 and $100 \%$ old man saltbush:elephant grass ratios, respectively (Figure 2). These 


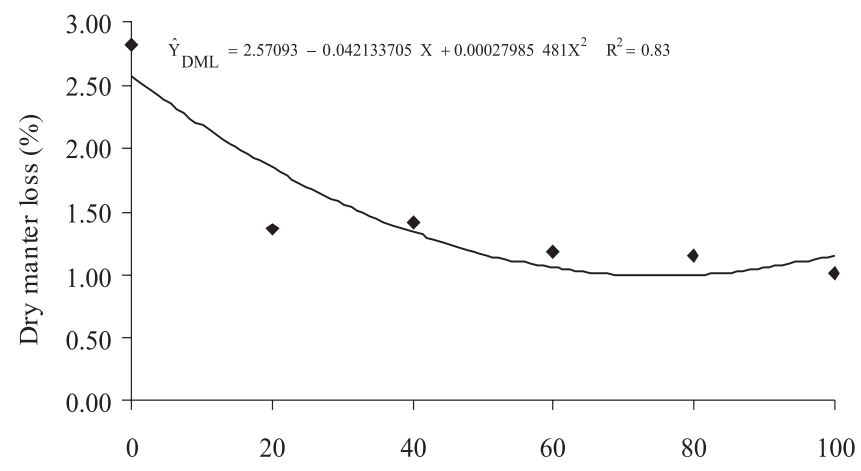

Figure 1 - Dry matter loss (DML) of the elephant grass with different old man saltbush levels.

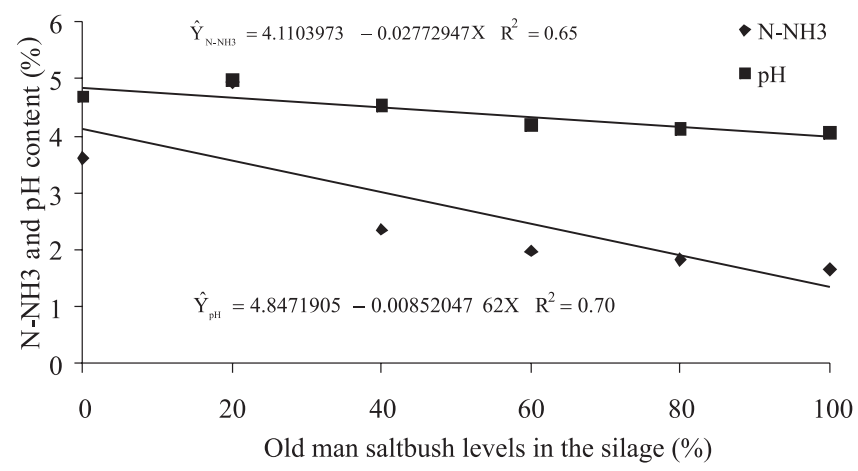

Figure 2 - Ammoniacal nitrogen ( $\mathrm{N}-\mathrm{NH}_{3}$ /total nitrogen) content and the $\mathrm{pH}$ of the elephant grass silage with different old man saltbush levels.

values were inferior to the maximum allowed (12\%) for the characterization of good-quality silages, i.e., there is the degradation of protein compounds (true protein, peptides, amino acids, amines and amides) by the bacteria of the Clostridium genus until ammonia, which is lost by volatilization during the opening of the silo (Candido et al., 2007).

Differences were observed $(\mathrm{P}<0.05)$ for the $\mathrm{pH}$ values (Figure 2) with the increase of old man saltbush in the elephant grass silage, with a linear decrease, which indicates efficient fermentation, i.e., $\mathrm{pH} \leq 4.40$ associated to the $30-40 \% \mathrm{DM}$ and also to the $10 \% \mathrm{~N}-\mathrm{NH}_{3}$ /total nitrogen (Tomich et al., 2003).

The increase in the amount of old man saltbush in the elephant grass silage promoted a $\mathrm{pH}$ decrease from 4.8 to 3.9 at the ratio of $100 \%$ old man saltbush (Figure 2); these values are in the acceptable range of 3.6 to 4.2, according to McDonald et al. (1991), which ensures good preservation of the ensiled materials. The results found testify the efficiency of the fermentation process.

The inclusion of old man saltbush in the silage affected the contents of lactic and acetic acids quadratically $(\mathrm{P}<0.05)$, without, however, changing the content of butyric acid (Figures 3 and 4). The maximum value of lactic acid estimated was $7.69 \%$ for the $84.03 \%: 15.97 \%$, old man saltbush:elephant grass ratio. The lactic acid value found in the silage was superior to $3.0 \%$, which characterizes good-quality silage (Vilela, 1990; Ferrari Júnior \& Lavezzo, 2001). The lactic acid has more accented acidification power in comparison with the other acids produced and, therefore, is the main acid responsible for the quick drop and maintenance of $\mathrm{pH}$.

Pires et al. (2009), evaluating the fermentation characteristics of elephant grass silages with coffee husks, cocoa meal or cassava meal, observed lactic acid values superior to $3.0 \%$, with average of $4.6 \%$. This average was lower to that found in this research. The acetic acid content was quadratic $(\mathrm{P}<0.05 \%)$, in which the $82.38 \%: 17.62 \%$ old man saltbush:elephant grass ratio obtained the lowest value corresponding to $0.17 \%$ and the highest value of $0.84 \%$ for this variable. Therefore, the values found for this variable are below the critical level of $0.8 \%$ of this acid.

The butyric acid contents did not present significance by the addition of old man saltbush levels in the silage (Figure 4). One can observe that the butyric acid and $\mathrm{N}-\mathrm{NH}_{3}$ values were relatively low, which indicates the absence of

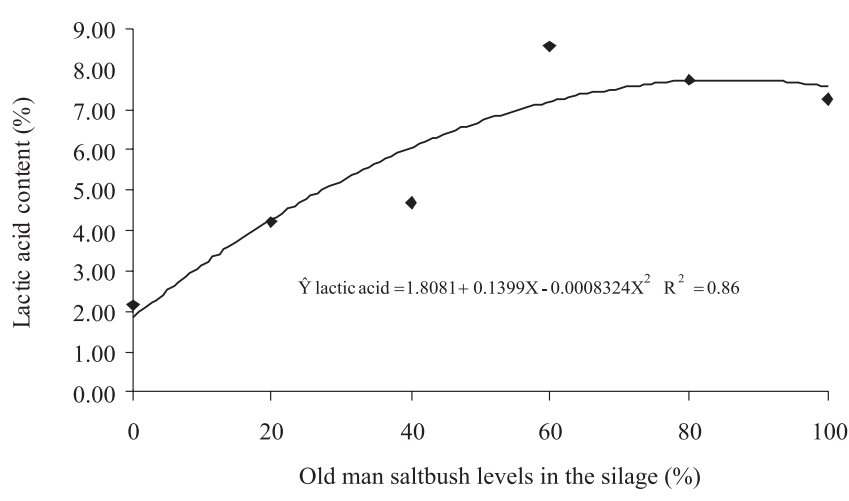

Figure 3 - Lactic acid content of the elephant grass silages with different old man saltbush levels.

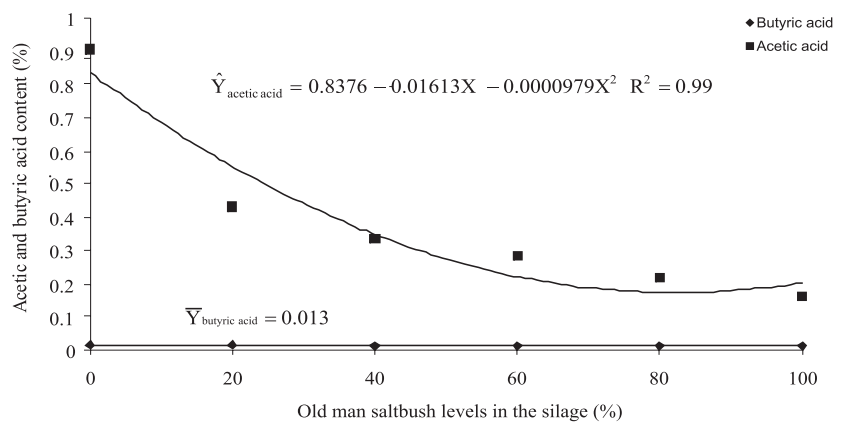

Figure 4 - Acetic and butyric acid contents of the elephant grass silages with different old man saltbush levels.

R. Bras. Zootec., v.41, n.6, p.1401-1406, 2012 
undesirable fermentations, resulting from the action of bacteria from the Clostridium genus, once these bacteria lead to the unfolding of sugars, lactic acid and amino acids with production of butyric and acetic acids, $\mathrm{N}_{-} \mathrm{NH}_{3}$, amines, ammonia and gases, reducing the nutritional value of the silage (McDonald, 1981).

The DM content of the silages was affected $(\mathrm{P}<0.05)$ by and presented increasing linear response to the old man saltbush levels in the silages (Figure 5). The DM contents in the silages are near the range recommended for forages stored in upright silos, which goes from 30 to 35\% DM (McDonald et al., 1991; Tomich et al., 2003), so that the old man saltbush DM content was $34.96 \%$ and, by increasing its level in the elephant grass silage, the silage DM also increased. This fact demonstrates the high potential of old man saltbush as additive in the ensilage of forage grasses with high moisture content or harvested when too young and that presents low DM content $(<20-25 \%)$. It is worth stressing that the DM content does not determine, by itself, the quality of the silage. Other variables, such as the soluble carbohydrate content of the plant can be good for fermentation, resulting in good-quality silage (Cândido et al., 2002).

According to the regression analysis, the increasing old man saltbush levels had linear effect $(\mathrm{P}<0.05)$ on the crude protein (CP) content of the silages (Figure 6), which elevated proportionally with the addition of old man saltbush, so the maximum value estimated at $9.81 \%$, corresponding to $100 \%$ old man saltbush, was achieved. This can be explained by the higher CP content of this plant, which varies from 14 to $17 \%$ (FAO, 1996), in relation to the elephant grass, where the CP content varies between 7 and 9\% (Machado et al., 2008).

The NDF content was not affected $(\mathrm{P}>0.05)$ by old man saltbush levels in the elephant grass silage; they were represented by the mean value of $54.15 \%$ (Figure 7). According to Van Soest (1965), NDF levels equal or superior to $70 \%$ limit feed intake by the physical effect of rumen filling. One can observe that the ADF contents of the silages were affected $(\mathrm{P}<0.05)$ by the increasing levels of old man saltbush (Figure 7), because there was decreasing linear behavior in the ADF contents. The ADF content was $30.55 \%$ at the $100 \%$ old man saltbush level.

The TCH values did not differ statistically $(\mathrm{P}>0.05)$ with the addition of old man saltbush in the elephant grass, presenting mean value of $73.93 \%$ (Figure 8 ). For its part, the NFC contents decreased with the increment of old man saltbush, presenting values from $24.85 \%$ to $15.72 \%$, for the 0 and $100 \%$ concentrations, respectively, with $9.13 \%$ accrual (Figure 8).
The quadratic regression model was significant for the variable IVDMD, presenting the following equation: $\hat{Y}_{\text {IVDMD }}=35.0354+0.3022 X-0.0024 X^{2}$ (Figure 9), which demonstrates the best $62.96 \%: 37.07 \%$ old man saltbush:elephant grass ratio, respectively, achieving maximum IVDMD value of $44.55 \%$, at this ratio. One can infer that the addition of the saltbush improved the energy

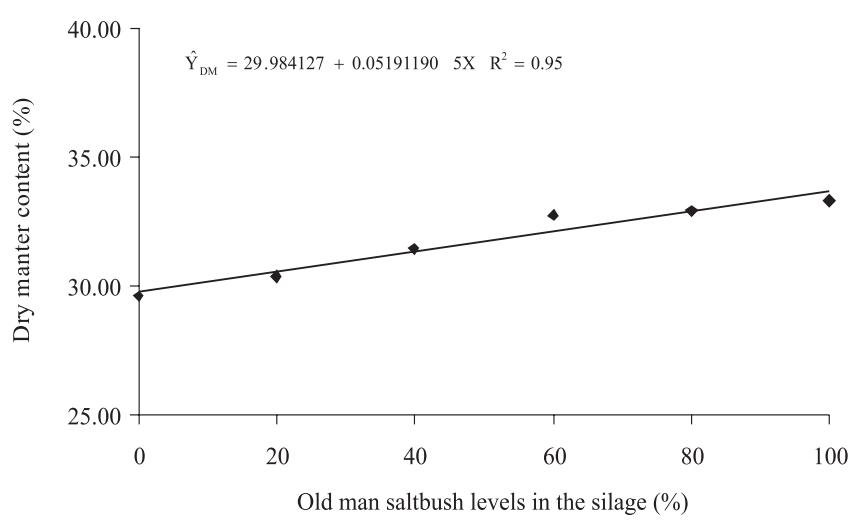

Figure 5 - Dry matter (DM) content of the elephant grass with different old man saltbush levels.

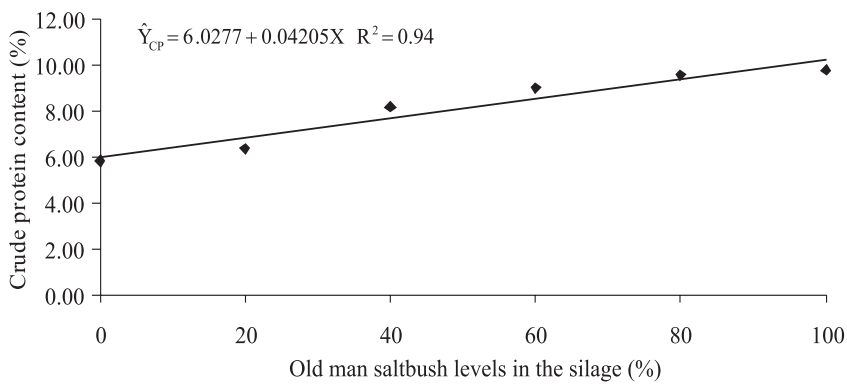

Figure 6 - Crude protein (CP) content of the elephant grass silage with different old man saltbush levels.

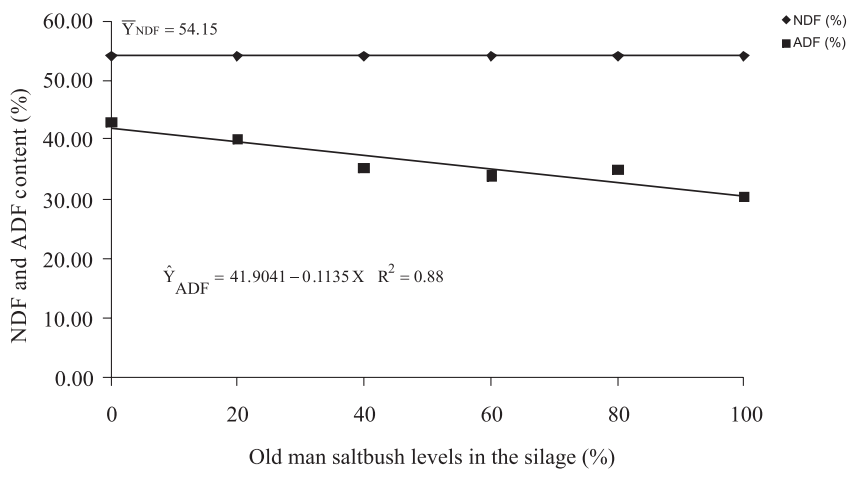

Figure 7 - Neutral and acid detergent fiber (NDF and ADF, respectively) contents of the elephant grass silage with different old man saltbush levels. 
contents of the elephant grass silages without, however, enabling levels above 55\% IVDMD, which would be more adequate for roughages. Such behavior may be related to the NDF contents observed, which practically kept constant and those of ADF and NFC, which decreased with the increase in old man saltbush in the silages. However, Pires et al. (2009), working with elephant grass ensiled with cassava meal, achieved higher values at 74.1\% IVDMD, indicated by the low lignin content in the cassava meal.

The ether extract (EE) values in the silages were not affected $(\mathrm{P}<0.05)$ with the inclusion of old man saltbush, presenting mean value of $1.67 \%$. According to the NRC (2007), the total amount of fat in the diet must not exceed 6 to $7 \%$ in the dry matter (DM), for it can bring reductions in the rumen fermentation at the fiber digestibility and its passage rate.

The inclusion of old man saltbush improved the fermentation process of elephant grass; this practice was beneficial to the ensilage and can be utilized by the farmer in the semi-arid conditions of Pernambuco.

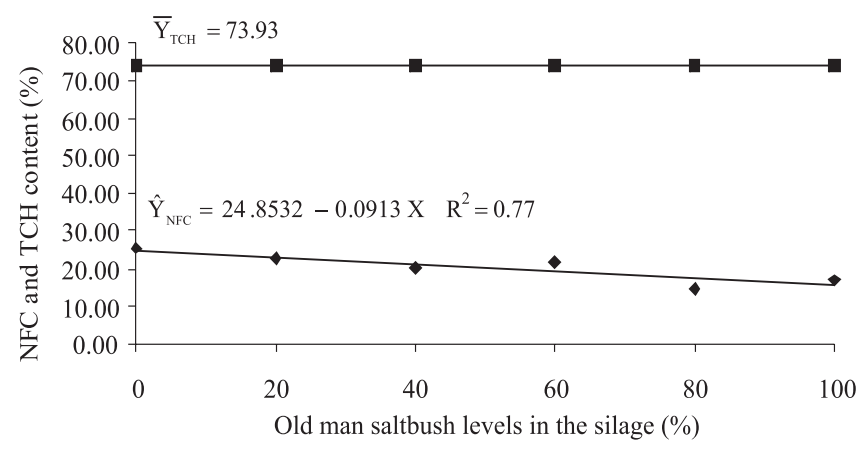

Figure 8 - Non-fibrous carbohydrates (NFC) and total carbohydrates $(\mathrm{TCH})$ content of the elephant grass silage with different old man saltbush levels.

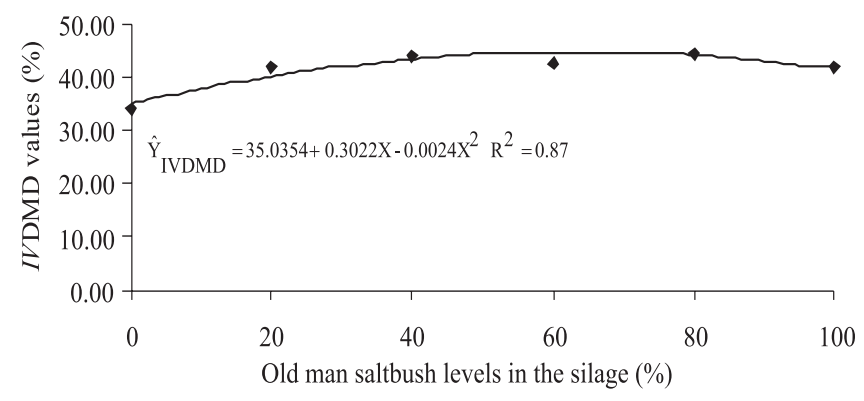

Figure 9 - In vitro dry matter digestibility (IVDMD) of the elephant grass silage with different old man saltbush levels.

\section{Conclusions}

The addition of old man saltbush during the ensilage of elephant grass improves the fermentation process, promoting good acid lactic contents and reducing the acetic acid, pH, dry matter loss and ammoniacal nitrogen. The nutritional quality of the elephant grass silages improves with the addition of old man saltbush, increasing the dry matter and crude protein contents without, however, diminishing the neutral detergent fiber contents or increasing the in vitro dry matter digestibility.

\section{References}

ASSOCIATION OF OFFICIAL AGRICULTURE CHEMISTS AOAC. Official methods of analyses of the Association of Agriculture Chemists. 13.ed. Washington, D.C.: 1980. 1015p.

BERNARDINO, F.S.; GARCIA, R.; ROCHA, F.C. et al. Produção e características do efluente e composição bromatológica da silagem de capim-elefante contendo diferentes níveis de casca de café. Revista Brasileira de Zootecnia, v.34, n.6, p.2185-2291, 2005.

CÂNDIDO, M.J.D.; OBEID, J.A.; PEREIRA, O.G. et al. Características fermentativas e potencial biológico de silagens de híbridos de sorgo cultivados com doses crescentes de adubação. Revista Ceres, v.49, p.151-167, 2002.

CÂNDIDO, M.J.D.; NEIVA, J.M.N.; RODRIGUEZ, N.M. et al. Características fermentativas e composição química de capimelefante contendo subproduto desidratado de maracujá. Revista Brasileira de Zootecnia, v.36, n.5, p.1489-1494, 2007.

CARVALHO, G.G.P.; GARCIA, R.; PIRES, A.J.V. et al. Valor nutritivo de silagens de capim-elefante emurchecido ou com adição de farelo de cacau. Revista Brasileira de Zootecnia, v.36, n.5, p.1495-1501, 2007.

FOOD AND AGRICULTURE ORGANIZATION OF THE UNITED NATIONS - FAO. Estudios de caso de espécies vegetales para zonas aridas y semiaridas de Chile y México. Santiago: Oficina Regional de la FAO para America Latina y el Caribe, 1996. 143p. (FAO. Oficina Regional para America Latina y el Caribe, Zonas Aridas y Semiaridas, 10).

FERRARI JÚNIOR, E.; LAVEZZO, W. Qualidade da silagem de capimelefante (Pennisetum purpureum, Schum) emurchecido ou acrescido e de farelo de mandioca. Revista Brasileira de Zootecnia, v.30, n.5, p.1424-1431, 2001.

KUNG JR., L.; RANJIT, N.K. The effect of Lactobacillus buchneri and other additives on the fermentation and aerobic stability of barley silage. Journal of Dairy Science, v.84, n.5, p.1149-1155, 2001.

MACHADO, P.A.S.; VALADARES FILHO, S.C.; VALADARES, R.F.D. et al. Avaliação nutricional do capim-elefante (Cameroon) em diferentes idades de rebrotação. Revista Brasileira de Zootecnia, v.37, n.6, p.1121-1128, 2008.

MACHADO, A.; CONCEIÇÃO, A.R. Versão 2.0 Programa estatístico WinStat sistema de análise estatística para Windows. Pelotas: UFPEL, 2002.

McDONALD, P., HENDERSON, N., HERON, S. The biochemistry of silage. 2.ed. Bucks: Chalcombe Publications, 1991. 340p.

McDONALD, P. The biochemistry of silage. New York: John Wiley \& Sons, 1981. 207p.

NATIONAL RESEARCH COUNCIL - NRC. Nutrient requirement of small ruminants. Washington, D.C., 2007. 362 p. 
PIRES, A.J.V. ; CARVALHO, G.G.P. ; GARCIA, R. et al. Capimelefante ensilado com casca de café, farelo de cacau ou farelo de mandioca. Revista Brasileira de Zootecnia, v.38, n.1, p.34-39, 2009.

SANTOS, M.V.F.; DUBEUX JÚNIOR, J.C.B.; MELLO, A.C.L. Formação e manejo de capineiras. In: LIRA, M.L.; SANTOS, M.V.F.; DUBEUX JÚNIOR, J.C.B. et al. (Eds.). Capim elefante: fundamentos e perspectivas. Recife: IPA-UFRPE, 2010. p.145-162.

SILVA, D.J.; QUEIROZ, A.C. Análise de alimentos: métodos químicos e biológicos. 3.ed. Viçosa, MG: UFV, 2002. 235p.

SNIFFEN, C.J. et al. A net carbohydrate and protein system for evaluating cattle diets: II. Carbohydrate and protein availability. Journal Animal Science, v.70, n.11, p.3562$3577,1992$.
TILLEY, J.A.; TERRY, A.R. A two-stage technique for in vitro digestion of forages crops. Journal British Grassland Society, v.18, n.1, p.104-111, 1963.

TOMICH, T.R.; PEREIRA, L.G.R. ; GONÇALVES, L.C. et al. Características químicas para avaliação do processo fermentativo de silagens: uma proposta para qualificação da fermentação. Corumbá: Embrapa Pantanal, 2003. p.30. (Documentos, 57).

VAN SOEST, P.J. Voluntary intake in relation to chemical composition and digestibility. Journal of Animal Science, v.24, n.3, p.834-843, 1965.

VILELA, D. Utilização do capim elefante na forma de forragem conservada. In: SIMPÓSIO SOBRE CAPIM-ELEFANTE, 1990, Coronel Pacheco. Anais... Juiz de Fora: Embrapa Gado de Leite, 1990. p.89-131. 